\title{
Expression of androgen receptor and its regulatory molecule Lin28 in non-luminal subtype breast cancer
}

\author{
DOONYAPAT SA-NGUANRAKSA ${ }^{1}$, WANEE PONGTHONG ${ }^{1,2}$, NORASATE SAMARNTHAI ${ }^{3}$, \\ KWANLADA MITPAKDI ${ }^{1,2}$, TUENJAI CHUANGSUWANICH ${ }^{3}$, THAWORNCHAI LIMJINDAPORN ${ }^{2}$, \\ ANCHALEE KULPROM $^{1}$ and PORNCHAI O-CHAROENRAT ${ }^{1}$ \\ ${ }^{1}$ Division of Head Neck and Breast Surgery, Department of Surgery; Departments of ${ }^{2}$ Anatomy and ${ }^{3}$ Pathology, \\ Faculty of Medicine, Siriraj Hospital, Mahidol University, Bangkok 10700, Thailand
}

Received July 24, 2019; Accepted February 18, 2020

DOI: $10.3892 / \mathrm{mco} .2020 .2029$

\begin{abstract}
Androgen receptor (AR) was associated with favourable outcome in luminal breast cancer. However, the role of AR in non-luminal breast cancer remains inconclusive. The aim of the present study was to evaluate the clinical significance of the AR and its regulatory pathway in non-luminal subtypes of breast cancer. In total, 284 breast cancer patients were recruited from January 2007 to January 2016. Tissue microarrays were constructed from archival paraffin blocks and assessed for AR and its regulatory molecule, Lin28, by immunohistochemistry. The association between AR and Lin28 expression and clinicopathological parameters was analyzed. Results showed that AR and Lin28 were co-expressed. No association between these proteins and clinicopathological parameters, and survival outcome was found. However, a higher proportion of the patients with AR and Lin28 expression were observed in HER2 subtype. In conclusion, Lin 28 may be a novel marker for prognosis and targeted for treatment in HER2 subtype breast cancer.
\end{abstract}

\section{Introduction}

Breast cancer is the most common malignancy in women worldwide, including Thailand, accounting for $25 \%$ of all cancers in women $(1,2)$. Hormone receptor $(\mathrm{HR})$-negative breast cancer or non-luminal breast cancer patients have a poorer outcome than other subtypes and lack of hormonal therapy for long-term control of the disease. Non-luminal breast cancer comprises triple negative breast cancer (TNBC) and HER2 subtypes. Due to a lack of target for

Correspondence to: Dr Pornchai O-Charoenrat, Division of Head Neck and Breast Surgery, Department of Surgery, Faculty of Medicine, Siriraj Hospital, Mahidol University, 2 Wanglang Road, Bangkok 10700, Thailand

E-mail: pornchai.och@mahidol.ac.th

Key words: androgen receptor, breast cancer, human epidermal growth factor receptor 2, Lin28, non-luminal subtypes therapy, systemic chemotherapy is the main treatment for TNBC. In addition, approximately $20-50 \%$ of HER2-positive patients showed resistance to Trastuzumab one year after treatment (3). Therefore, identification of novel prognostic markers and alternative treatments is imperative for both subtypes.

Androgen receptor (AR), a class I steroid receptor is commonly expressed up to $70 \%$ in primary breast cancer and approximately $50-75 \%$ in metastatic breast cancer $(4,5)$. In luminal subtype breast cancer, AR co-expression was associated with better outcomes $(6,7)$. AR expression was a significant prognostic factor for disease-free survival (DFS), overall survival (OS) and decreased risk of metastasis of non-luminal subtype breast cancer in some studies (8-10). By contrast, androgen can induce proliferation of AR-positive/estrogen receptor (ER)-negative cells as commonly found in molecular apocrine subtype which had AR expression of approximately 50\% (11-13). Previous studies reported that RNA binding protein, Lin28A (referred to as Lin28 in this study), which regulates let-7 miRNA, stimulates HER 2 expression and alters AR promoter activity (14-16). The upregulation of Lin28 in adults leads to carcinogenesis and progressive cell proliferation in several malignancies, including breast cancer (17-20). However, the role of these proteins in non-luminal breast cancer remains controversial. The aim of the present study was to evaluate the clinical significance of AR and Lin28 in non-luminal subtype breast cancer. It was found that AR and Lin28 are co-expressed. Thus, Lin28 may be a novel marker for prognosis and targeted for treatment in HER2 subtype breast cancer.

\section{Patients and methods}

Patients and data collection. In total, 284 patients were retrospectively recruited at the Division of Head Neck and Breast Surgery, Department of Surgery, Faculty of Medicine, Siriraj Hospital, Mahidol University (Bangkok, Thailand) from January 2007 to January 2016. The patients with pathological stage I-III, invasive ductal breast carcinomas, age at diagnosis equal to or more than 20 years, and HR negative were included. The sample size was determined by the formula for estimation of infinite population proportion using parameters 
from a previous study (15). The proportions of Ki-67 status were 0.375 and 0.197 in groups 1 and 2 . The ratios of proportion in both groups were 2.590 (according to AR expression), $\alpha=0.05,2$-sided test, and power $80 \%$. This resulted in a sample size of 239. To achieve statistically significant difference and the expected $10 \%$ dropout of the patients, the total sample size was approximately 250 cases. The current study was approved by the ethics committee of the Faculty of Medicine Siriraj Hospital, Mahidol University, Bangkok, Thailand (COA no. Si733/2016). This study was performed in a retrospective manner, therefore, no informed consent was obtained from the patients.

The data collected from medical records comprised age at diagnosis, pathological reports, surgical procedure, adjuvant treatment (chemotherapy, hormonal therapy, targeted therapy, and radiotherapy), and follow-up data. Repository formalin fixed-paraffin embedded (FFPE) breast cancer and non-neoplasm control tissues (prostate, tonsil, and testis) in excess of standard pathological examination were obtained from the Department of Pathology, Faculty of Medicine, Siriraj Hospital, Mahidol University. The case record forms did not indicate any identification that linked to individual patients.

Tissue microarray (TMA). All H\&E-stained slides and corresponding paraffin blocks of each case including non-cancerous breast tissues were collected and reviewed. The selected areas mapped on donor paraffin blocks were punched by manual microarrayer with diameter $2 \mathrm{~mm}$ for 3 cores and placed into the applied recipient mold. Each mold was melted at $60^{\circ} \mathrm{C}$ for $6 \mathrm{~min}$ and re-embedded. Finally, each slide contained triplicate of 17 cases, negative, and positive tissue controls. The TMA blocks were sliced into $4 \mu \mathrm{m}$ thickness. The section ribbon was placed on the slide glass and air dried for $30 \mathrm{~min}$.

Immunohistochemistry. Expression of AR and Lin28 was assessed by immunohistochemistry (IHC) using mouse monoclonal anti-human AR (AR441, dilution 1:300, Dako) and mouse monoclonal anti-human Lin28A (55CT58.12.1, dilution 1:75, Sigma-Aldrich). AR staining was performed by semi-autostainer (Agilent Technologies, Dako; Autostainer Link 48). Deparaffinization, rehydration, and antigen retrieval were performed by target retrieval solution high pH (pH 9.0) at $95^{\circ} \mathrm{C}$ with PT Link (Dako PT link). Lin28 staining was performed by manual procedure. PT Link (Dako PT link) with target retrieval solution high $\mathrm{pH}$ ( $\mathrm{pH}$ 9.0) was used. The sections were incubated overnight at $4^{\circ} \mathrm{C}$ with primary antibody. Subsequently, the sections were warmed up at room temperature $\left(25^{\circ} \mathrm{C}\right)$ and rinsed twice with PBS. Peroxidase-blocking solution (Dako Peroxidase Blocking Code SM801) was used for endogenous blocking for approximately $5 \mathrm{~min}$ and then rinsed twice with PBS for $10 \mathrm{~min}$. The sections were incubated with HRP-conjugated secondary antibody (Envision FLEX-HRP Code SM802) for $20 \mathrm{~min}$. The visualization step was performed with Envision FLEX DAB and Chromogen (Envision FLEX DAB and Chromogen Code DM827) for 12 min and then rinsed with tap water for $5 \mathrm{~min}$. The sections were counterstained with hematoxylin. Finally, the sections were dehydrated with alcohol series (95 and 100\% alcohol and acetone, respectively) and cleared with xylene.

The protein expression level was calculated by a mean score of 3 cores. The AR-positive status was determined by an established cut-off value of $>20 \%$ of nucleus staining. Lin 28 status was evaluated by cytoplasmic staining and scored according to the Modified Allred Scoring system including staining intensity and percentage of positive cells. The sum of staining and percentage was classified as: 0-2, negative and 3-8, positive. Scoring was performed by two experienced breast pathologists who did not know the clinical data of patients.

Dual in situ hybridization (DISH). For HER2 equivocal cases (IHC score 2+), HER2 amplification status was assessed by dual color in situ hybridization (DISH). The process was performed by using a cocktail-specific probe for HER2 and chromosome 17 (Chr 17) on a single slide. The HER2 copies were detected using the HER2 DNP-labeled probe and visualized via ultraView SISH detection kit [Ventana ultraView SISH dinitrophenyl (DNP), Ventana Medical System, USA]. Centromeres of chromosome 17 were assigned by Chr17 DIG-labeled probe and visualized by ultraView Red ISH detection kit [Ventana ultraViewRed ISH digoxigenin (DIG), Ventana Medical System]. DISH staining was performed by auto-staining system (BenchMark XT automated slide stainer, Ventana). The black signal (HER2) to red signal (Chr 17) ratio was manually counted by light microscope at a magnification, $\mathrm{x} 20$ for 20 cells and calculated. The ratios of equal or more than 2.0 were considered as HER2 amplification.

Statistical analysis. Associations between protein expression and clinicopathological parameters were analyzed using a Chi-square test. Binary logistic regression was performed for multivariate analysis using backward conditional method. Survival analysis was performed by Log-rank test and survival curves were estimated by Kaplan-Meier method. The DFS time was calculated from the date of surgery to the date of cancer reccurrence, metastasis or death. The OS time was calculated from the date of surgery to the date of death. The Cox proportional hazards model was applied for prediction of survival rate. Multivariate analysis was performed by Cox regression to evaluate the effect of independent prognostic factors on DFS and OS. The SPSS software version 21 was used for statistical analysis. $\mathrm{P}<0.05$ was considered to indicate a statistically significant difference.

\section{Results}

Patient characteristics. A total of 284 patients were eligible and recruited in this study. Patient characteristics are presented in Table I. HER2 equivocal cases by IHC were further assessed for HER2 amplification by DISH (Fig. 1). The mean age at diagnosis was 55.39 years ( \pm 11.36 years). There were 131 HER2 subtype breast cancer patients and 24 patients receiving HER2-targeted therapy. TNBC subtype was 153 cases. Two hundred and two patients (71.1\%) were post-menopause. The mean tumor size was $20.9 \mathrm{~mm}$ $( \pm 10.5 \mathrm{~mm})$. A tumor size $>20 \mathrm{~mm}$ was found in 190 cases 
Table I. Demographics data of non-luminal subtype patients.

\begin{tabular}{|c|c|}
\hline Parameters & Number, $\mathrm{n}=284(\%$ \\
\hline Age at diagnosis & $55.39( \pm 11.36)$ \\
\hline \multicolumn{2}{|c|}{ Age at diagnosis [n (\%)] } \\
\hline$\leq 50$ years & $87(30.6)$ \\
\hline$>50$ years & $197(69.4)$ \\
\hline \multicolumn{2}{|l|}{ Tumor size $[\mathrm{n}(\%)]$} \\
\hline$\leq 20 \mathrm{~mm}$ & $94(33.1)$ \\
\hline$>20-50 \mathrm{~mm}$ & $172(60.6)$ \\
\hline$>50 \mathrm{~mm}$ & $18(6.3)$ \\
\hline \multicolumn{2}{|c|}{ Histological grading [n (\%)] } \\
\hline II & $93(32.7)$ \\
\hline III & $191(67.3)$ \\
\hline \multicolumn{2}{|c|}{ Lymphovascular invasion [n (\%)] } \\
\hline Absence & $201(70.8)$ \\
\hline Presence & $83(29.2)$ \\
\hline \multicolumn{2}{|c|}{ Axillary nodal metastasis [n (\%)] } \\
\hline No & $166(58.5)$ \\
\hline Yes & $118(41.5)$ \\
\hline \multicolumn{2}{|l|}{$\mathrm{N}$ stage $[\mathrm{n}(\%)]$} \\
\hline No & $166(58.5)$ \\
\hline N1 & $59(20.8)$ \\
\hline N2 & $28(9.9)$ \\
\hline N3 & $31(10.9)$ \\
\hline \multicolumn{2}{|l|}{ Staging $[\mathrm{n}(\%)]$} \\
\hline $\mathrm{I}$ & $73(25.7)$ \\
\hline II & $143(50.4)$ \\
\hline III & $168(23.9)$ \\
\hline \multicolumn{2}{|c|}{ HER-2 status [n (\%)] } \\
\hline Negative & $153(53.9)$ \\
\hline Positive & $131(46.1)$ \\
\hline \multicolumn{2}{|c|}{ HER-2 targeted therapy $[\mathrm{n}(\%)]^{\mathrm{a}}$} \\
\hline No & 107 (81.7) \\
\hline Yes & $24(18.3)$ \\
\hline
\end{tabular}

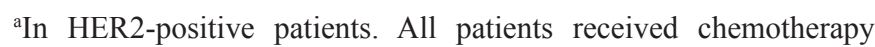
according to clinical practice guidelines.

$(66.9 \%)$. Approximately half of the patients were in stage II at diagnosis (143 cases, $50.4 \%$ ). There was no grade I tumor while the majority of the patients had grade III tumor (67.3\%). All the patients received chemotherapy according to clinical practice guidelines and completed the course of treatment.

$A R$ and Lin28 expression. AR was expressed in 66 of 284 non-luminal tumors $(23.2 \%)$. AR expression was detected in $45(68.2 \%)$ and 21 cases $(31.8 \%)$ in HER2 and TNBC subtype, respectively. Lin28 protein was detected in 201 out of 284 patients $(70.8 \%)$. From these, 164, 34, and 3 patients had weak, moderate, and strong AR staining, respectively. Ninety-two TNBC and 109 HER2 patients had Lin28 expression (Figs. 2-3).
Association between protein expression and clinicopathological parameters. Among 284 patients, AR and Lin28 status was significantly associated with HER2-positive status. In addition, both proteins were co-expressed together in non-luminal breast cancer (Tables II-III). Multivariate analysis revealed that AR-positive status was associated with the absence of axillary lymph node metastasis $(\mathrm{OR}=0.428$, 95\% CI 0.224-0.817, $\mathrm{P}=0.010)$, HER2-positive ( $\mathrm{OR}=2.948$, 95\% CI 1.555-5.587, $\mathrm{P}=0.001)$, and Lin28-positive status $(\mathrm{OR}=15.756,95 \%$ CI 3.707-66.979, $\mathrm{P}<0.001)$. Lin 28 expression was associated with HER2-positive $(\mathrm{OR}=2.562,95 \% \mathrm{CI}$ 1.426-4.603, $\mathrm{P}=0.002)$, and $\mathrm{AR}$ positive status $(\mathrm{OR}=15.437$, $95 \%$ CI 3.649-65.312, $\mathrm{P}<0.001)$.

Survival analysis. The median follow-up time was 43 months (1-139 months). There were 51 events that occurred during follow up including 3 loco-regional recurrences, 12 metastases, and 36 deaths. Two hundred and thirty-three patients were alive without disease. Univariate analysis via log-rank test revealed that tumor size, pathological staging, axillary lymph node metastasis, and lymphovascular invasion (LVI) were associated with lower DFS $(\mathrm{P}=0.042, \mathrm{P}<0.001$, $\mathrm{P}<0.001$ and $\mathrm{P}<0.001$, respectively). Pathological staging, axillary lymph node metastasis, and LVI were associated with lower OS $(\mathrm{P}<0.001, \mathrm{P}<0.001$ and $\mathrm{P}<0.001$, respectively). Multivariate analysis revealed that pathological stage and LVI were the strong independent factors for DFS (HR=2.769, 95\% CI 1.383-5.544, $\mathrm{P}=004$ and $\mathrm{HR}=2.748,95 \%$ CI $1.391-5.428$, $\mathrm{P}=004$, respectively) and $\mathrm{OS}(\mathrm{HR}=3.160,95 \%$ CI $1.347-7.415$, $\mathrm{P}=0.008$ and $\mathrm{HR}=3.615,95 \%$ CI $1.533-8.525, \mathrm{P}=0.003$, respectively). The survival curves among HER 2 and TNBC subtypes by AR and Lin28 status are shown in Fig. 4. There was no significant difference in survival among different AR and Lin28 status.

\section{Discussion}

The present study demonstrated the associations between the expression of AR and Lin28 in non-luminal breast cancer. In HER2-overexpressed breast cancer, we also showed the association between the expression of Lin28 and HER2.

A higher proportion of AR expression was observed in HER 2 subtype in the present study. Similar studies by Micello et al (21) and Park et al (22), showed that AR expression was often detected in ER-negative/HER2-positive breast cancer. The implications of HER 2 and AR have been suggested in molecular basis. HER2 is a transcriptional target of AR and able to activate ERK activity $(11,12)$. In vitro studies suggested that androgen can induce proliferation in AR-positive/ER-negative cells such as those commonly found in the molecular apocrine subtype which exhibited AR co-expression of approximately $50 \%(3,13)$. He et al reported that treatment with Enzalutamide, an AR antagonist, reduced the ability of tumor growth via decreased cell proliferation and increased cell death in HER2-positive breast cancer, both in vitro and in vivo (3). AR-positive/ER-negative in HER2 overexpression or amplification in breast cancer has been reported to be associated with unfavourable outcome when compared to those with AR-negative (5,22-24). However, in the present study, we did not find any significant association 


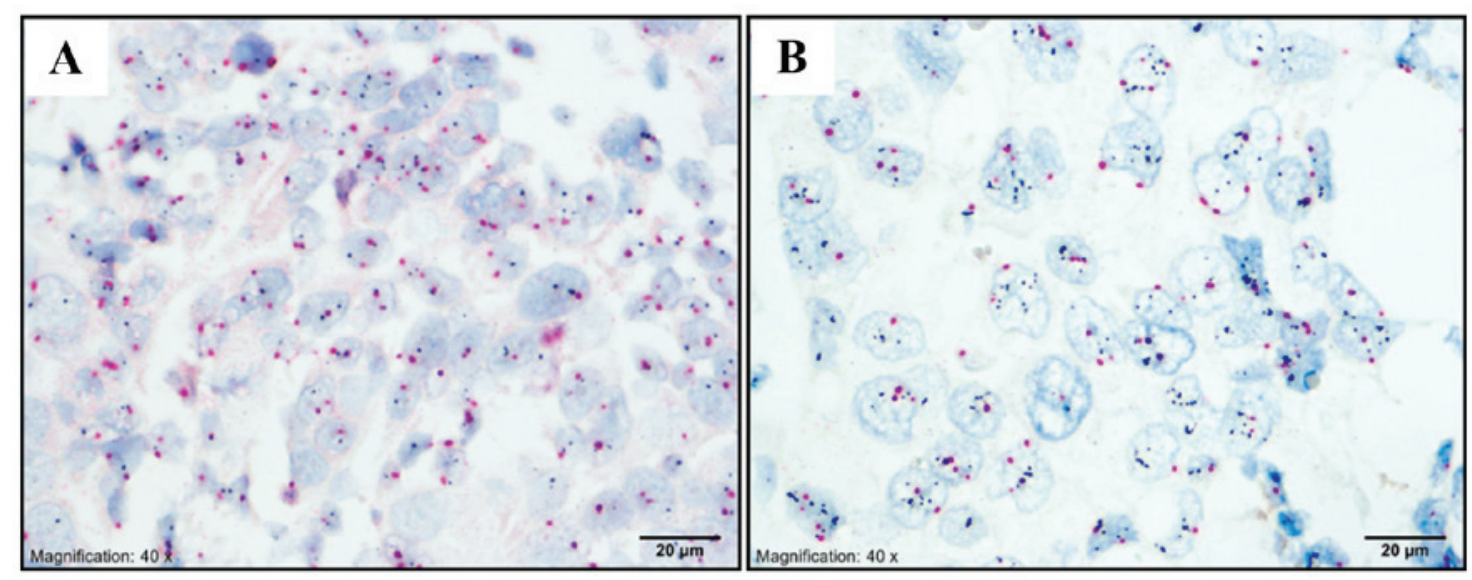

Figure 1. HER2 DISH was used to assess HER2 amplification in the patients with equivocal HER2 immunohistochemistry. (A) Breast cancer cells with a low level of HER2 signal. (B) Breast cancer cells with HER2 amplification.

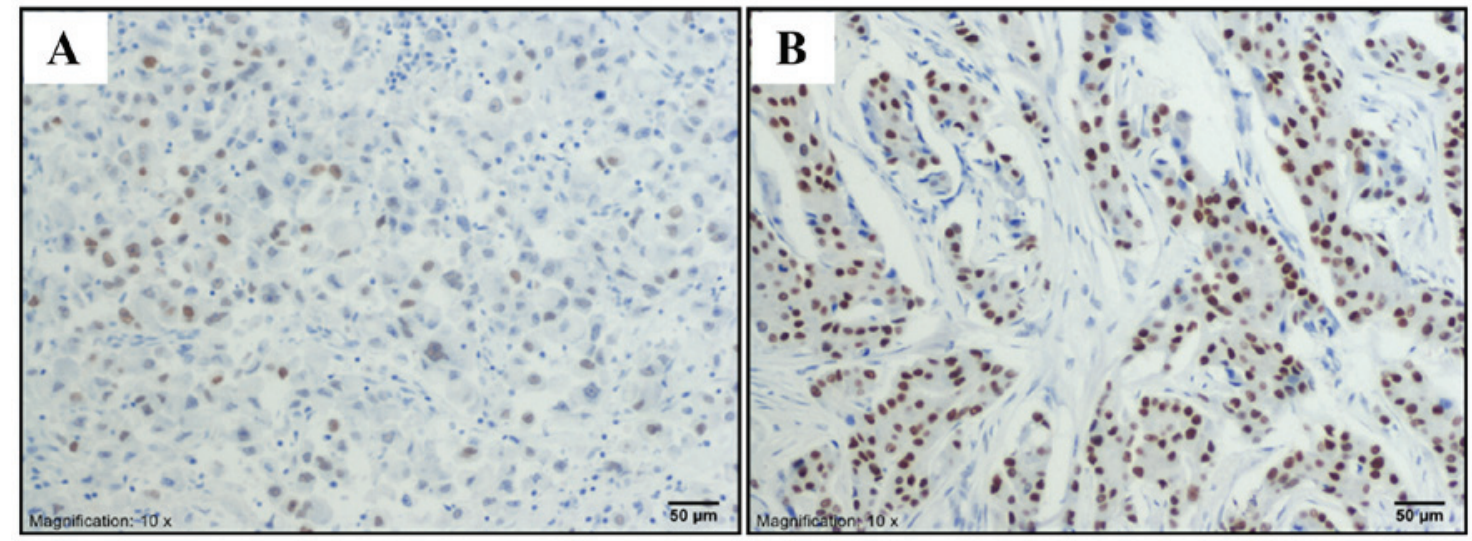

Figure 2. Immunostaining of AR. (A) AR-negative status, percentage of cells staining range, $0-20 \%$. (B) AR-positive status, percentage of cells staining $>20 \%$. Magnification, $x 10$.

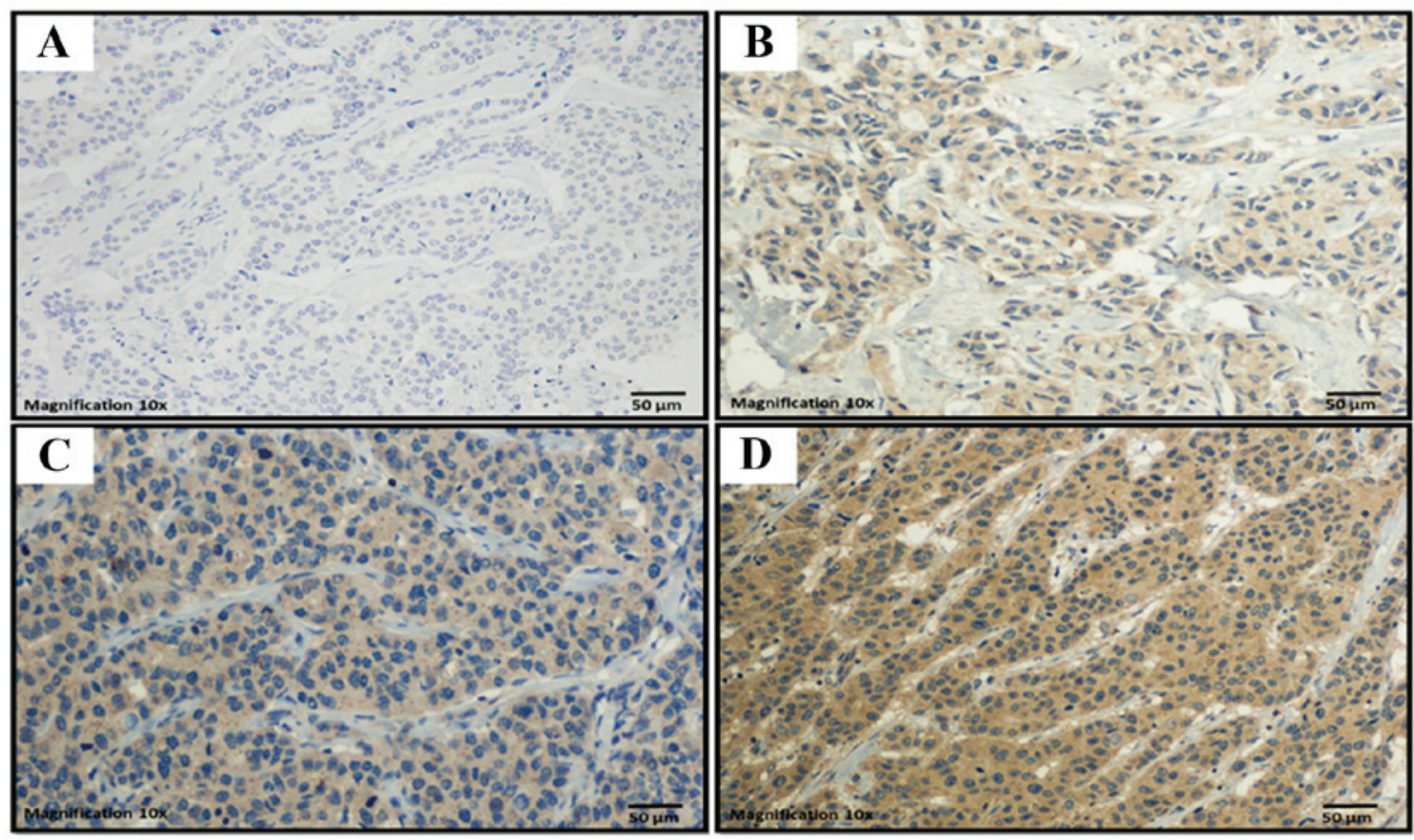

Figure 3. The cytoplasmic staining levels of Lin28. (A) Negative staining, (B) weak staining: 1+, (C) moderate staining: $2+$, (D) strong intensity: $3+$. Magnification, $x 10$. 
Table II. Associations between AR expression and clinicopathological parameters in non-luminal subtype.

\begin{tabular}{|c|c|c|c|c|c|c|c|}
\hline \multirow[b]{2}{*}{$\begin{array}{l}\text { Clinicopathological } \\
\text { parameters }\end{array}$} & \multicolumn{4}{|c|}{$\mathrm{AR}(\mathrm{n}=284)$} & \multicolumn{3}{|c|}{ Multivariate analysis ${ }^{\mathrm{a}}$} \\
\hline & $\begin{array}{l}\text { Negative, } \\
\text { n }(\%)\end{array}$ & $\begin{array}{l}\text { Positive, } \\
\mathrm{n}(\%)\end{array}$ & OR $(95 \% \mathrm{CI})$ & P-value & $\operatorname{Exp}(B)$ & $95 \% \mathrm{CI}$ & P-value \\
\hline \multicolumn{8}{|l|}{ Age (years) } \\
\hline$\leq 50$ & $69(31.7)$ & $18(27.3)$ & 1 (ref.) & 0.499 & 1.106 & $0.562-2.176$ & 0.770 \\
\hline$>50$ & $149(68.3)$ & $48(72.7)$ & $1.235(0.669-2.278)$ & & & & \\
\hline \multicolumn{8}{|l|}{ Tumor size (mm) } \\
\hline$\leq 20$ & $66(30.3)$ & $28(42.4)$ & 1 (ref.) & 0.068 & 0.705 & $0.369-1.348$ & 0.291 \\
\hline$>20$ & $152(69.7)$ & $38(57.6)$ & $0.589(0.334-1.039)$ & & & & \\
\hline \multicolumn{8}{|l|}{ Histological grading } \\
\hline II & $70(32.1)$ & $23(34.8)$ & 1 (ref.) & 0.678 & 1.030 & $0.532-1.996$ & 0.930 \\
\hline III & $148(67.9)$ & $43(65.2)$ & $0.884(0.495-1.580)$ & & & & \\
\hline \multicolumn{8}{|l|}{ Pathological staging } \\
\hline I, II & $166(76.1)$ & $53(80.3)$ & 1 (ref.) & 0.482 & 1.325 & $0.495-3.545$ & 0.575 \\
\hline III & $52(23.9)$ & $13(19.7)$ & $0.783(0.396-1.549)$ & & & & \\
\hline \multicolumn{8}{|c|}{ Axillary node metastasis } \\
\hline No & $121(55.5)$ & $45(68.2)$ & 1 (ref.) & 0.069 & 0.428 & $0.224-0.817$ & $0.010^{\mathrm{b}}$ \\
\hline Yes & $97(44.5)$ & $21(31.8)$ & $0.582(0.325-1.043)$ & & & & \\
\hline \multicolumn{8}{|l|}{$\begin{array}{l}\text { Perinodal invasion } \\
(\mathrm{pN}+\text { patients })\end{array}$} \\
\hline Absent & $49(50.5)$ & $12(57.1)$ & 1 (ref.) & 0.582 & 0.643 & $0.233-1.779$ & 0.396 \\
\hline Present & $48(49.5)$ & $9(42.9)$ & $0.766(0.300-1.983)$ & & & & \\
\hline \multicolumn{8}{|l|}{ Perineural invasion } \\
\hline Absent & $207(95.0)$ & $63(95.5)$ & 1 (ref.) & 0.869 & 0.661 & $0.164-2.667$ & 0.561 \\
\hline Present & $11(5.0)$ & $3(4.5)$ & $0.896(0.242-3.312)$ & & & & \\
\hline \multicolumn{8}{|l|}{ LVI } \\
\hline Absent & $150(68.8)$ & $51(77.3)$ & 1 (ref.) & 0.187 & 0.919 & $0.418-2.024$ & 0.835 \\
\hline Present & $68(31.2)$ & $15(22.7)$ & $0.649(0.341-1.234)$ & & & & \\
\hline \multicolumn{8}{|l|}{ HER2 status } \\
\hline Negative & $132(60.6)$ & $21(31.8)$ & 1 (ref.) & $<0.001^{\mathrm{b}}$ & 2.948 & $1.555-5.587$ & $0.001^{\mathrm{b}}$ \\
\hline Positive & $86(39.4)$ & $45(68.2)$ & $3.289(1.833-5.903)$ & & & & \\
\hline \multicolumn{8}{|l|}{ Lin28 status } \\
\hline Negative & $81(37.2)$ & $2(3.0)$ & 1 (ref.) & $<0.001^{\mathrm{b}}$ & 15.756 & $3.707-66.979$ & $<0.001^{\mathrm{b}}$ \\
\hline Positive & $137(62.8)$ & $64(97.0)$ & $18.92(4.510-79.373)$ & & & & \\
\hline
\end{tabular}

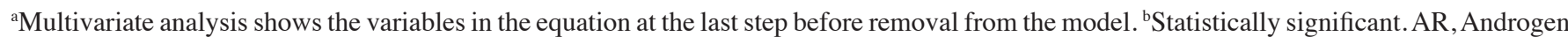
receptor; LVI, lymphovascular invasion; OR, odds ratio; 95\% CI, 95\% confident interval.

between AR expression and unfavourable clinicopathological parameters or worse survival outcomes.

One of the main AR transcriptional regulatory cascades involves let-7 and Lin28. Lin28 is an RNA-binding protein (RBP) that directly regulates let-7 miRNA. Aberration thereof could lead to carcinogenesis and progressive cell proliferation in breast cancer (25). In the HER2 subtype, the association between AR expression and Lin28-positive status was detected in the present study. Lin28 regulates the expression of AR via c-myc, a proto-oncogene involved in cell proliferation (16). The study by Feng et al also demon- strated the relationship between Lin28 expression and ER negative/HER2-positive in breast cancer cell (14). The Lin28 responsive element (LRE) is 200 nucleotides in length and is located in nearly $5^{\prime}$ end of the coding region of HER2 mRNA. The authors suggested that HER 2 mRNA contains a cis-acting element that is specifically recognized by Lin 28 within the coding region and activates translation in breast cancer. An 'A' bulge flanked by two GC base pairs in the secondary structure of HER 2 mRNA served as the binding site for Lin 28 (26). Shen et al, reported that Lin28 and AR were co-expressed in ER-negative/HER2-positive breast 
Table III. Associations between Lin28 expression and clinicopathological parameters in non-luminal subtype.

\begin{tabular}{|c|c|c|c|c|c|c|c|}
\hline \multirow[b]{2}{*}{$\begin{array}{l}\text { Clinicopathological } \\
\text { parameters }\end{array}$} & \multicolumn{4}{|c|}{$\operatorname{Lin} 28(n=284)$} & \multicolumn{3}{|c|}{ Multivariate analysis ${ }^{\mathrm{a}}$} \\
\hline & $\begin{array}{l}\text { Negative, } \\
\text { n }(\%)\end{array}$ & $\begin{array}{l}\text { Positive, } \\
\text { n }(\%)\end{array}$ & OR $(95 \% \mathrm{CI})$ & P-value & $\operatorname{Exp}(\mathrm{B})$ & $95 \% \mathrm{CI}$ & P-value \\
\hline \multicolumn{8}{|l|}{ Age (years) } \\
\hline$\leq 50$ & $28(33.7)$ & $59(29.4)$ & 1 (ref.) & 0.467 & 0.927 & $0.503-1.709$ & 0.808 \\
\hline$>50$ & $55(66.3)$ & $142(70.6)$ & $1.225(0.709-2.117)$ & & & & \\
\hline \multicolumn{8}{|l|}{ Tumor size (mm) } \\
\hline$\leq 20$ & $23(27.7)$ & $71(35.3)$ & 1 (ref.) & 0.216 & 0.743 & $0.403-1.368$ & 0.340 \\
\hline$>20$ & $60(72.3)$ & $130(64.7)$ & $0.702(0.401-1.230)$ & & & & \\
\hline \multicolumn{8}{|l|}{ Histological grading } \\
\hline II & $24(28.9)$ & $69(34.3)$ & 1 (ref.) & 0.377 & 0.893 & $0.484-1.650$ & 0.718 \\
\hline III & $59(71.1)$ & $132(65.7)$ & $0.778(0.446-1.358)$ & & & & \\
\hline \multicolumn{8}{|l|}{ Pathological staging } \\
\hline $\mathrm{I}, \mathrm{II}$ & $66(79.5)$ & $153(76.1)$ & 1 (ref.) & 0.536 & 1.298 & $0.635-2.655$ & 0.474 \\
\hline III & $17(20.5)$ & $48(23.9)$ & $1.218(0.653-2.273)$ & & & & \\
\hline \multicolumn{8}{|c|}{ Axillary node metastasis } \\
\hline No & $49(59.0)$ & $117(58.2)$ & 1 (ref.) & 0.898 & 1.065 & $0.483-2.344$ & 0.877 \\
\hline Yes & $34(41.0)$ & $84(41.8)$ & $1.035(0.615-1.740)$ & & & & \\
\hline \multicolumn{8}{|l|}{ Perinodal invasion } \\
\hline \multicolumn{8}{|l|}{ (pN+ patients) } \\
\hline Absent & $19(55.9)$ & $42(50.0)$ & 1 (ref.) & 0.563 & 1.196 & $0.553-2.583$ & 0.650 \\
\hline Present & $15(44.1)$ & $42(50.0)$ & $1.267(0.569-2.821)$ & & & & \\
\hline \multicolumn{8}{|l|}{ Perineural invasion } \\
\hline Absent & $81(97.6)$ & $189(94.0)$ & 1 (ref.) & 0.223 & 2.324 & $0.479-11.290$ & 0.296 \\
\hline Present & $2(2.4)$ & $12(6.0)$ & $2.571(0.563-11.750)$ & & & & \\
\hline \multicolumn{8}{|l|}{ LVI } \\
\hline Absent & $56(67.5)$ & $145(72.1)$ & 1 (ref.) & 0.432 & 0.823 & $0.450-1.506$ & 0.527 \\
\hline Present & $27(32.5)$ & $56(27.9)$ & $0.801(0.461-1.393)$ & & & & \\
\hline \multicolumn{8}{|l|}{ HER 2 status } \\
\hline Negative & $61(73.5)$ & $92(45.8)$ & 1 (ref.) & $<0.001^{\mathrm{b}}$ & 2.562 & $1.426-4.603$ & $0.002^{\mathrm{b}}$ \\
\hline Positive & $22(26.5)$ & $109(54.2)$ & $3.285(1.875-5.756)$ & & & & \\
\hline \multicolumn{8}{|l|}{ AR status } \\
\hline Negative & $81(97.6)$ & $137(68.2)$ & 1 (ref.) & $<0.001^{\mathrm{b}}$ & 15.437 & $3.649-65.312$ & $<0.001^{\mathrm{b}}$ \\
\hline Positive & $2(2.4)$ & $64(31.8)$ & $18.920(4.510-79.373)$ & & & & \\
\hline
\end{tabular}

${ }^{\mathrm{a}}$ Multivariate analysis shows the variables in the equation at the last step before removal from the model. ${ }^{\mathrm{b}}$ Statistically significant. LVI, lymphovascular invasion; OR, odd ratio; $95 \% \mathrm{CI}=95 \%$ confident interval.

cancer tissues and cell lines, suggesting a worse survival outcome $(15,16)$.

In the present study, the positive association between AR and Lin 28 was noted. However, only one-third of positive Lin 28 breast cancer patients have positive AR expression. In ER-negative/HER2-positive breast cancer, several signaling cascades including the upregulation of Wnt and c-myc were involved in the interaction between AR and HER2 $(12,27)$. Lin 28 can activate the proliferation and growth of tumor cells via Lin28/let7 pathway (20). Patients with Lin28 expression tended to have a lower survival rate compared to patients without Lin28 expression in HER2 subtype. This result was in accordance with previous studies regarding the potential role of Lin28 in decreased tumor suppressor miRNA and increased oncoproteins in breast cancer $(15,16,18,28-30)$.

In conclusion, this current results have demonstrated the role of Lin28 in HER2-overexpressed breast cancer and showed the potential prognostic factor. Thus, Lin 28 may be a novel marker for prognosis and future-targeted therapy for HER2 subtype breast cancer. 
A

HER-2 subtype

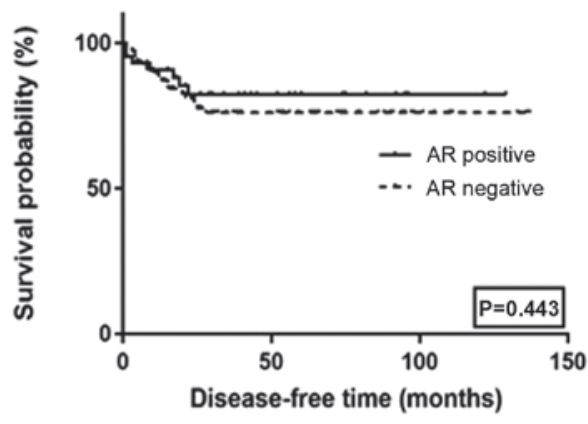

TNBC subtype

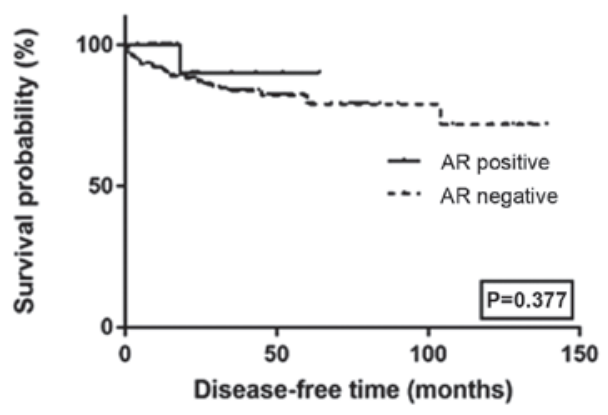

B

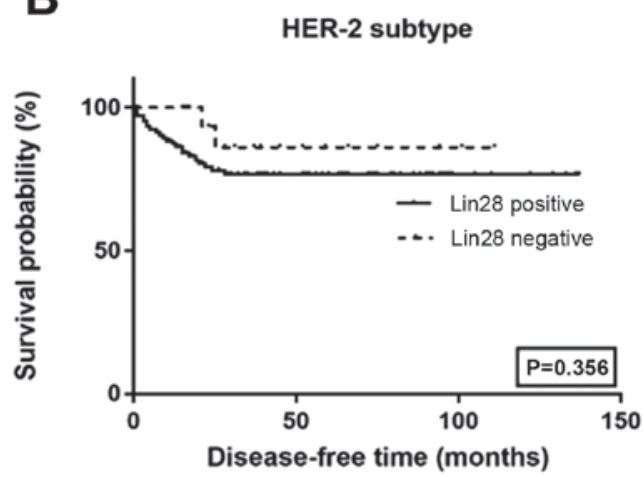

TNBC subtype

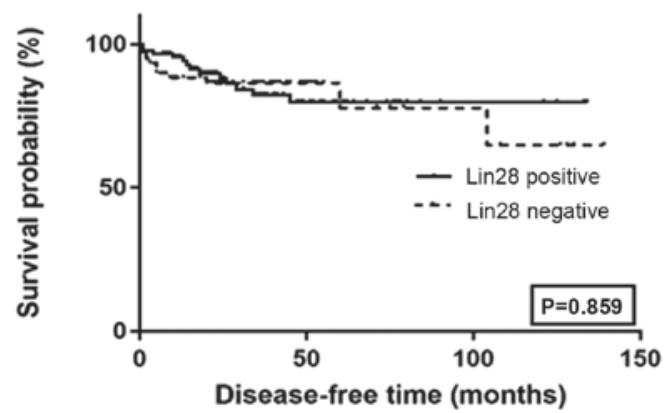

HER-2 subtype

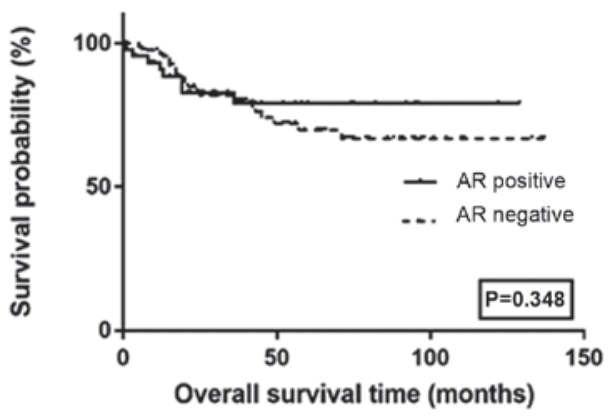

TNBC subtype



HER-2 subtype

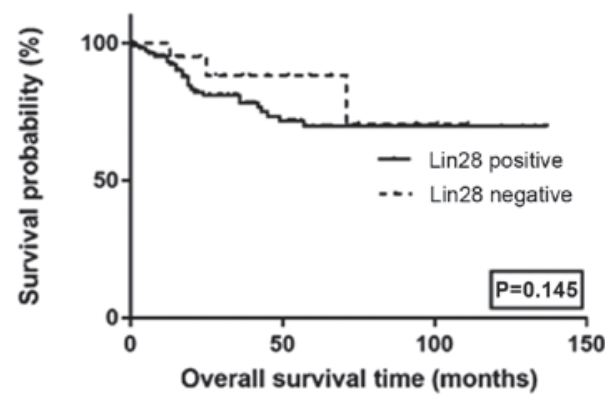

TNBC subtype

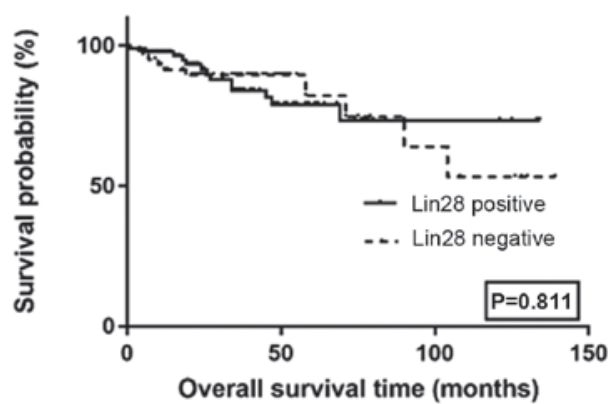

Figure 4. Survival curves of HER2 and TNBC subtypes according to AR and Lin28 status. (A) DFS and OS by AR status in HER2 and TNBC breast cancer. There was no significant difference in survival between different AR statuses. (B) DFS and OS by Lin2 8 status in HER2 and TNBC breast cancer. There was no significant difference in survival between different Lin28 statuses.

\section{Acknowledgements}

We would like to thank Miss Surat Phumphuang (Division of Head Neck and Breast Surgery, Department of Surgery, Faculty of Medicine, Siriraj Hospital, Mahidol University) for helping with data collection and manuscript preparation.

\section{Funding}

This study was supported by Siriraj Graduate Scholarship and Siriraj Grant for Research Development and Medical Education, Faculty of Medicine Siriraj Hospital, Mahidol University (grant no. R016133002). 


\section{Availability of data and materials}

The datasets generated and/or used during the present study are available from the corresponding author on reasonable request.

\section{Authors' contributions}

DS, WP, KM, AK, TL and PO prepared the manuscript. DS and PO treated the patients. NS and TC performed pathological examination and data collection. WP, KM performed data collection and the statistical analysis. PO provided the concept of the study and finalized the manuscript. All authors read and approved the final manuscript.

\section{Ethics approval and consent to participate}

This study has been approved by the ethics committee of the Faculty of Medicine, Siriraj Hospital, Mahidol University (Bangkok, Thailand; COA no. Si733/2016).

\section{Patient consent for publication}

Not applicable.

\section{Competing interests}

The authors declare that they have no competing interests.

\section{References}

1. Sa-Nguanraksa D, Chuangsuwanich T, Pongpruttipan T and O-Charoenrat P: High vascular endothelial growth factor gene expression predicts poor outcome in patients with non-luminal A breast cancer. Mol Clin Oncol 3: 1103-1108, 2015.

2. Sa-Nguanraksa D, Sasanakietkul T, O-Charoenrat C, Kulprom A and O-Charoenrat P: Gail model underestimates breast cancer risk in thai population. Asian Pac J Cancer Prev 20: 2385-2389, 2019.

3. He L, Du Z, Xiong X, Ma H, Zhu Z, Gao H, Cao J, Li T, Li H, Yang $\mathrm{K}$, et al: Targeting androgen receptor in treating HER2 positive breast cancer. Sci Rep 7: 14584, 2017.

4. Hickey TE, Robinson JL, Carroll JS and Tilley WD: Minireview: The androgen receptor in breast tissues: Growth inhibitor, tumor suppressor, oncogene? Mol Endocrinol 26: 1252-1267, 2012.

5. Rahim B and O'Regan R: AR signaling in breast cancer. Cancers (Basel) 9: E21, 2017.

6. Hu R, Dawood S, Holmes MD, Collins LC, Schnitt SJ, Cole K, Marotti JD, Hankinson SE, Colditz GA and Tamimi RM: Androgen receptor expression and breast cancer survival in postmenopausal women. Clin Cancer Res 17: 1867-1874, 2011.

7. Peters AA, Buchanan G, Ricciardelli C, Bianco-Miotto T, Centenera MM,Harris JM, Jindal S, Segara D, JiaL, Moore NL, et al: Androgen receptor inhibits estrogen receptor-alpha activity and is prognostic in breast cancer. Cancer Res 69: 6131-6140, 2009.

8. Rampurwala M, Wisinski KB and O'Regan R: Role of the androgen receptor in triple-negative breast cancer. Clin Adv Hematol Oncol 14: 186-193, 2016.

9. Jiang HS, Kuang XY, Sun WL, Xu Y, Zheng YZ, Liu YR, Lang GT, Qiao F, Hu X and Shao ZM: Androgen receptor expression predicts different clinical outcomes for breast cancer patients stratified by hormone receptor status. Oncotarget 7: 41285-41293, 2016.

10. Sutton LM, Cao D, Sarode V, Molberg KH, Torgbe K, Haley B and Peng Y: Decreased androgen receptor expression is associated with distant metastases in patients with androgen receptor-expressing triple-negative breast carcinoma. Am J Clin Pathol 138: 511-516, 2012.

11. Naderi A and Hughes-Davies L: A functionally significant cross-talk between androgen receptor and ErbB2 pathways in estrogen receptor negative breast cancer. Neoplasia 10: 542-548, 2008.
12. Chia KM, Liu J, Francis GD and Naderi A: A feedback loop between androgen receptor and ERK signaling in estrogen receptor-negative breast cancer. Neoplasia 13: 154-166, 2011.

13. Robinson JL, Macarthur S, Ross-Innes CS, Tilley WD, Neal DE, Mills IG and Carroll JS: Androgen receptor driven transcription in molecular apocrine breast cancer is mediated by Fox A1. EMBO J 30: 3019-3027, 2011.

14. Feng C, Neumeister V, Ma W, Xu J, Lu L, Bordeaux J, Maihle NJ, Rimm DL and Huang Y: Lin28 regulates HER2 and promotes malignancy through multiple mechanisms. Cell Cycle 11: 2486-2494, 2012.

15. Shen H, Yang Y, Zhao L, Yuan J and Niu Y: Lin28A and androgen receptor expression in ER-/Her2+ breast cancer. Breast Cancer Res Treat 156: 135-147, 2016.

16. Shen H, Zhao L, Feng X, Xu C, Li C and Niu Y: Lin28A activates androgen receptor via regulation of $\mathrm{c}$-myc and promotes malignancy of ER-/Her2+ breast cancer. Oncotarget 7: 60407-60418, 2016.

17. Viswanathan SR, Powers JT, Einhorn W, Hoshida Y, Ng TL, Toffanin S, O'Sullivan M, Lu J, Phillips LA, Lockhart VL, et al: Lin 28 promotes transformation and is associated with advanced human malignancies. Nat Genet 41: 843-848, 2009.

18. Viswanathan SR and Daley GQ: Lin28: A microRNA regulator with a macro role. Cell 140: 445-449, 2010.

19. Yang J, Bennett BD, Luo S, Inoue K, Grimm SA, Schroth GP, Bushel PR, Kinyamu HK and Archer TK: LIN28A modulates splicing and gene expression programs in breast cancer cells. Mol Cell Biol 35: 3225-3243, 2015.

20. Balzeau J, Menezes MR, Cao S and Hagan JP: The LIN28/let-7 pathway in cancer. Front Genet 8: 31, 2017.

21. Micello D, Marando A, Sahnane N, Riva C, Capella C and Sessa F: Androgen receptor is frequently expressed in HER2-positive, ER/PR-negative breast cancers. Virchows Arch 457: 467-476, 2010.

22. Park S, Koo J, Park HS, Kim JH, Choi SY, Lee JH, Park BW and Lee KS: Expression of androgen receptors in primary breast cancer. Ann Oncol 21: 488-492, 2010.

23. Ni M, Chen Y, Lim E, Wimberly H, Bailey ST, Imai Y, Rimm DL, Liu XS and Brown M: Targeting androgen receptor in estrogen receptor-negative breast cancer. Cancer Cell 20: 119-131, 2011.

24. Pietri E, Conteduca V, Andreis D, Massa I, Melegari E, Sarti S, Cecconetto L, Schirone A, Bravaccini S, Serra P, et al: Androgen receptor signaling pathways as a target for breast cancer treatment. Endocr Relat Cancer 23: R485-498, 2016.

25. Nguyen LH and Zhu H: Lin28 and let-7 in cell metabolism and cancer. Transl Pediatr 4: 4-11, 2015.

26. Lei XX, Xu J, Ma W, Qiao C, Newman MA, Hammond SM and Huang Y: Determinants of mRNA recognition and translation regulation by Lin28. Nucleic Acids Res 40: 3574-3584, 2012.

27. Ni M, Chen Y, Fei T, Li D, Lim E, Liu XS and Brown M: Amplitude modulation of androgen signaling by c-MYC. Genes Dev 27: 734-748, 2013.

28. Mayr F and Heinemann U: Mechanisms of Lin28-mediated miRNA and mRNA regulation-a structural and functional perspective. Int J Mol Sci 14: 16532-16553, 2013.

29. Tsialikas J and Romer-Seibert J: LIN28: Roles and regulation in development and beyond. Development 142: 2397, 2015.

30. Thammaiah CK and Jayaram S: Role of let-7 family microRNA in breast cancer. Noncoding RNA Res 1: 77-82, 2016.



This work is licensed under a Creative Commons Attribution-NonCommercial-NoDerivatives 4.0 International (CC BY-NC-ND 4.0) License. 